\title{
Development, Reliability and Validity of Anxiety Level Inventory (ALI)
}

\section{Mohammad Aziz Shah Mohamed Arip, Nurul Azura Zazali, Siti Zaleha Sheikh Mustafa@ Sheikh Hamid}

To Link this Article: http://dx.doi.org/10.6007/IJARBSS/v12-i1/11044

DOI:10.6007/IJARBSS/v12-i1/11044

Received: 04 November 2021, Revised: 06 December 2021, Accepted: 23 December 2021

Published Online: 11 January 2022

In-Text Citation: (Arip et al., 2022)

To Cite this Article: Arip, M. A. S. M., Zazali, N. A., \& Hamid, S. Z. S. M. @ S. (2022). Development, Reliability and Validity of Anxiety Level Inventory (ALI). International Journal of Academic Research in Business and Social Sciences, 12(1), $484-494$.

\section{Copyright: (c) 2022 The Author(s)}

Published by Human Resource Management Academic Research Society (www.hrmars.com)

This article is published under the Creative Commons Attribution (CC BY 4.0) license. Anyone may reproduce, distribute, translate and create derivative works of this article (for both commercial and non0-commercial purposes), subject to full attribution to the original publication and authors. The full terms of this license may be seen at: http://creativecommons.org/licences/by/4.0/legalcode

Vol. 12, No. 1, 2022, Pg. $484-494$

Full Terms \& Conditions of access and use can be found at http://hrmars.com/index.php/pages/detail/publication-ethics 


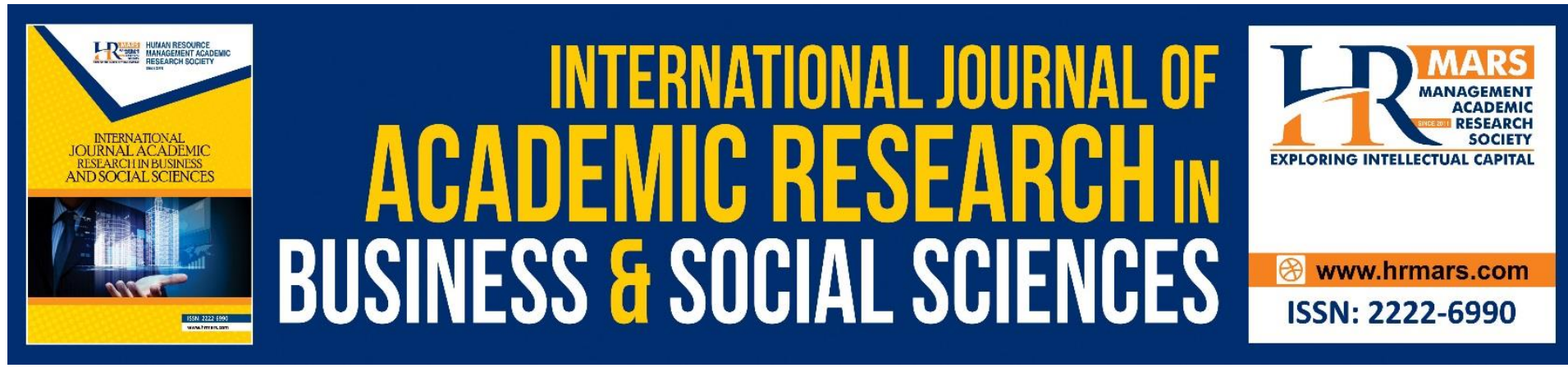

\title{
Development, Reliability and Validity of Anxiety Level Inventory (ALI)
}

\author{
Mohammad Aziz Shah Mohamed Arip \\ Professor, Faculty of Human Development, Sultan Idris Education University, 35900 Tanjong \\ Malim, Perak, Malaysia \\ Email: aziz.shah@fpm.upsi.edu.my
}

Nurul Azura Zazali

Faculty of Human Development, Sultan Idris Education University, 35900 Tanjong Malim, Perak, Malaysia

Email: edcounseling.psy@gmail.com

\author{
Siti Zaleha Sheikh Mustafa @ Sheikh Hamid \\ Faculty of Human Development, Sultan Idris Education University, 35900 Tanjong Malim, \\ Perak, Malaysia \\ Email: edcounseling.psy@gmail.com
}

\begin{abstract}
This study was designed to build and test the validity and reliability of the Anxiety Level Inventory (ALI). The ALI questionnaire was developed to assess the level of anxiety of an individual. This inventory is un-dimensional as it is built on the symptoms of anxiety, behavioral and cognitive disorders based on the theory of General Anxiety Disorder (GAD). This Anxiety Level Inventory is easy to administer as it only takes 10 to 15 minutes. This inventory is suitable to run at the age of 15 and above, male and female gender and multicultural. This test is also appropriate to administer in groups or individually. The inventory consisted of 21 items consisting of negative and positive statements to prevent respondents from responding to the inventory arbitrarily. This Anxiety Level Inventory uses the Likert scale of Never, Sometimes and Always. The validity of ALI content was evaluated by 12 experts comprising of government and private staff, as well as guidance and counseling teachers. A total of 82 respondents answered this ALI through a 'Google doc' application consisting of UPSI students as well as guidance and counseling students. Overall validity was moderate to high of 0.617 (61.7\%). The reliability value shows a high value of Cronbach alpha with .865. As such, this study produced an ALI questionnaire with good validity and reliability for use in the field of guidance and counseling in Malaysia.
\end{abstract}

Keywords: Anxiety Level Inventory, Content Validity, Reliability, General Anxiety Disorder (GAD), Counseling 


\section{Introduction}

Anxiety was defined as a person's made up interpretation towards an environmental stressor or burden which already had occurred, currently occurring or will be occur. Iso-Ahola and Hatfield (1986), mentioned that anxiety is a combination of physiological and psychological effect due to one's self interpretation on a situation. Gould and Krane (1992) explained anxiety as an emotional dimension or a revival for cognitive. A worrying feeling or anxiety is not an overwhelming experience in a human's life. This worrying feeling can make a human's life in anxiety, fear, strain and stressed. It can happen at any range of ages, does not matter if the person is a kid, teenager or an adult. If the person is having an anxiety, their emotional and behavioral changes can also occur. Based on the educational context, anxiety is a form of psychological disturbance towards the students and it needs the help from the teachers and school counsellors to overcome the disturbance. Kelly (1955) mentioned that human used constructive systems to predict things that will happen in their life and worries existed when we experience an event outer from our comfort zone. Conger (1985) define anxiety as an important determination to discover human's behavior. In addition, the one's existed anxiety was resulted from their painful experience, as example the pain they felt during their childhood and the anxiety feelings developed when they are in their adulthood. Meanwhile, Dollar and Miller (1950) mentioned that anxiety occurred because children tend have a lot of frustrated feelings. Anxiety behavior can affect the inner response towards their feelings, thoughts, psychological action and behavioral conflict. Freud (1997) stated that it is important to focus on their behavior instead of feelings this is because behaviors can change, but in the reality, humans can't lead themselves to feel better but they can lead themselves to do better things. With that, if a person can do good deeds, they can also build good feelings.

\section{Background of Anxiety Level Inventory (ALI)}

Anxiety is defined as an interpretation made in the shape of stress or burden in the environment either already occur, currently occurred and will be occur. Iso-Ahola and Hatfield (1986) explained that anxiety is a combination on the psychological and physiological effect occurred due to one's interpretation towards a situation. Gould and Krane (1992) explained anxiety as an emotional dimension or a cognitive revival. Anxiety Level Inventory was built to assess a person's potential towards their anxiety level. This inventory is unidimensional because it was build based on the anxiety symptoms consist of emotions, behaviour and also cognitive. This inventory is easily to be administered because it only took 10 to 15 minutes to be completed. This inventory is suitable for those who were 15 years old and above, men and women from different races. This test can also be administered in a group setting or an individual setting. It consists of 21 items which include a negative and positive statement to avoid the respondents answered the inventory carelessly. This Anxiety Level Inventory used a Likert scale such as Never, Sometimes and Always.

\section{Literature Review}

Anxiety is an uncomfortable feeling such as fear, worriedness and nervous. It is a usual thing occurred time by time. This feeling sometimes can make us feel prepared to face the unfavourable situation. The literature review in this research explains about the anxiety level based on theoretical basis. In a study by Mohamed and Zairazi (2007), conducted to understand the relationship between anxiety and performance as explained in the Multidimensional Anxiety Theory. The main purpose of this study was to identify the extent to which cognitive anxiety and somatic anxiety affect the performance of university male 
athletes. It is expected that cognitive anxiety and somatic anxiety are related to performance. A total of 125 male athletes from one a university involved in inter-private Sports tournaments between the ages of 18-45 years old were involved in this study. Data from respondents were collected using the Competitive State Anxiety Inventory - 2 (CSAI-2) measure introduced by (Martens et al., 1990). Respondents were required to complete a questionnaire 30 minutes before the competition began. The results of the study indicate that cognitive anxiety has a significant influence on performance. While somatic anxiety does not affect performance. Through the ANOVA Test, it was found that there was no significant difference between cognitive anxiety and somatic anxiety among the university teams participating in the Sports of the Private University of Malaysia Sports Council.

Based on a study by Mokhtarinejad, Mirzaian and Hassanzadeh (2020) on comparison between schema therapy and acceptance commitment therapy (ACT) in cognitive emotion regulation components on patients with anxiety disorder. This quasi-experimental study with a pre and post-test design involves two experimental group and one control group with 15 participants in each group. The result of the study proves that both type of therapy was effective in cognitive emotion regulation among the anxiety patients with $\mathrm{P}<0.001$ and it was suggested for therapist to implement the schema and acceptance commitment therapy in psychological interventions and cognitive emotion regulations with anxiety patients. A research by Tarhan, Karaman and Nalbant (2020) on examining counseling service as a pre and post study design with university students in Turkey. The finding of this study proves that psychological counselling service provides a statistically significant decrease in anxiety symptoms for the students (clients). This study was supported with a similar study by Demir and Yildirim (2017), which they have implemented eight sessions including conscious awareness, art and therapy using semi-experimental design in one group of students with anxiety. The result shows that there is a significant reduce in the student's anxiety level. With that, these studies had proven clinical counseling is important to guide and assist university students reducing their anxiety level.

\section{Importance of Study}

Anxiety disturbance is a mental health disorder that caused the suffering that have an over worrying followed by feeling of fear and anxiety that influence daily life. The importance of this research is to assess the potential level of anxiety within a person. This inventory is unidimensional because it was build based on the anxiety symptoms such as emotion, behavioural and cognitive. These are the list of symptoms on the level of anxiety occurred to a person who have ALI problems:

1. Feeling anxious with parents

2. Used to experience trauma

3. Have these type of personality:

- Shy

- Self-isolation

- Feeling anxious

With that, this research was built because of wanting to know the level of anxiety on one's self and identify patient's anxiety problem based on the inventory made. 


\section{Development of Anxiety Level Inventory (ALI)}

The Anxiety Level Inventory was build based on the early symptoms of anxiety disorder that a person may have. The Anxiety Level was characterized in three episodes which were Disconnection and Rejection, Impaired Autonomy and Performance and Over vigilance and Inhibition. With that, as based on the General Anxiety Disorder (GAD) theory, these three characteristics was used as the main element in the development of this inventory. This theory gives benefits to the patients who were diagnosed with mood disorders and anxiety where this scheme represents an individual emotional state including certain EMS that was activated in certain time with the right condition on scheme theory. With that, even though these two elements can be measure separately, their basis were still related to each other.

\section{Theoretical Basis on Anxiety Level Inventory Development}

The Anxiety Level Inventory (ALI) was build based on Jeffrey Young Schema Theory for patients with chronic psychological disease and failed to get well with traditional therapy. Jeffrey Young Schema Theory was the result of Beck Cognitive Model named Cognitive Behavioral Therapy (CBT) referred on mood disturbance and anxiety. By using the Young Shema Questionnaire - Third Edition (YS3Q), there are 18 early maladaptive schemas that was founded by Young and his colleagues and it was categorize into five schema domains which are:

\begin{tabular}{|c|c|c|}
\hline Schemes Domain & $\begin{array}{c}\text { EMS } \\
\text { (Early Maladaptive Schemas) }\end{array}$ & Explanation \\
\hline Disconnection and Rejection & $\begin{array}{l}\text { 1. Neglect } \\
\text { 2. Disbelief / Abuse } \\
\text { 3. Emotional abuse } \\
\text { 4. Deficiency / Shyness } \\
\text { 5.Social Isolation / Isolate }\end{array}$ & $\begin{array}{l}\text { Believe that other people } \\
\text { would leave them } \\
\text { - Believe that other people } \\
\text { would lie and take an } \\
\text { advantage } \\
\text { - Feeling that the emotional } \\
\text { support is not available } \\
\text { - Believe that a person is } \\
\text { disable and not worth } \\
\text { anything } \\
\text { - Feeling left out from others }\end{array}$ \\
\hline $\begin{array}{l}\text { Impaired Autonomy and } \\
\text { Performance }\end{array}$ & $\begin{array}{l}\text { 6. Independency / Inefficiency } \\
\text { 7. Vulnerability for Damages / } \\
\text { Disease } \\
\text { 8. Alliance / Self-development } \\
\text { 9. Fails }\end{array}$ & $\begin{array}{l}\text { - Feeling that one's could not } \\
\text { take care of themselves } \\
\text { - Believe that any disasters } \\
\text { would occur } \\
\text { - Combination of identity with } \\
\text { others } \\
\text { - Believe that someone is not } \\
\text { enough compared to others }\end{array}$ \\
\hline Over vigilance and Inhibition & $\begin{array}{l}\text { 10. Negativity / Pessimist } \\
\text { 11. Emotional Barrier } \\
\text { 12. Standards/Hyper criticalness } \\
\text { 13. Punitive }\end{array}$ & $\begin{array}{l}\text { - } \text { A broad focus on the negative } \\
\text { - } \text { aspects } \\
\text { - } \text { Life } \\
\text { - } \quad \text { Strive forional constrains } \\
\text { - } \quad \text { Believe that making a mistake } \\
\text { will be punished }\end{array}$ \\
\hline
\end{tabular}


Overall, people need to need to be aware about anxiety disorder to identify their own health condition. One of the worrying things could happen is when a person acts normally on the outside but in the reality, they are having a disease on the inside of them.

\section{Research Objectives}

The purpose of this research:

a. Development of ALI inventory based on literature reviews.

b. To obtain the reliability value of the inventory based on the professional's evaluations.

c. To obtain the reliability value on each of the subscales of the inventory based on the professional's evaluations.

d. To determine the validity value of the inventory.

e. To determine the validity value on each of the sub-scales of the inventory.

\section{Anxiety Level Inventory Administration, Scoring and Interpretation}

The Anxiety Level Inventory was built to assess the anxiety disease potential towards people. This inventory has a unidimensional characteristic because it was build based on the anxiety disorder symptoms such as emotions, behaviors and cognitive. This inventory can be administered easily because it only took 10 to 15 minutes only. It is suitable for those who age from 15 years old and above, men and women and different cultures. It is also can be administered by group or individual. Respondents were free to answer any statements based on their own opinion. They were also will be advised to answer the inventory honestly and sincerely on the statement that reflects themselves. The answers need to be ticked in the answer space in the answer sheet given based on the Likert scale, Never, Sometimes and Always. The inventory consists of 21 items and use the Likert scale such as Never, Sometimes and Always. The value provided in the Likert scale is 0 for Never, 1 for Sometimes and 2 for Always. This inventory consists of 21 items include with 3 subscales (Refer to Table 1).

Table 1: Number of items in each subscale

\begin{tabular}{lc}
\hline \multicolumn{1}{c}{ Sub Scales } & Number of Item \\
\hline Emotions (disconnection and denial) & 7 \\
Behaviors (autonomy impairment and achievement) & 7 \\
Cognitive (vigilance and blocking) & 7 \\
\hline
\end{tabular}

Total score for the inventory is 42 and for each subscale is 14 . The inventory score interpretation was analyzed and divided into several levels, low levels denoted by 0 until 13 marks, moderate level with 14 until 28 marks and high level with 29 until 42 marks (Referred to Table 2). Meanwhile, the sub scale score interpretation and analysis were also divided into three level which are low level by scoring from 0 to 4 marks, moderate level with 5 to 9 marks and high with 10 to 14 marks (Look on Table 3). These interpretations can lead to the respondent's evaluation on their anxiety level. 
Table 2: Inventory Score Interpretation of ALI

\begin{tabular}{lll}
\hline Level & Total Score & Interpretation \\
\hline High & $29-42$ & Level of anxiety is on the highest level \\
Moderate & $14-28$ & Level of anxiety is on the moderate level \\
Low & $0-13$ & Level of anxiety is on the low level \\
\hline
\end{tabular}

Table 3: Inventory Subscale Score Interpretation of ALI

\begin{tabular}{ccl}
\hline Level & Total Score & \multicolumn{1}{c}{ Interpretation } \\
\hline High & $10-14$ & $\begin{array}{l}\text { Level of anxiety is on the highest level based on } \\
\text { the subscale factors. } \\
\text { Level of anxiety is on the moderate level based } \\
\text { on the subscale factors. } \\
\text { Level of anxiety is on the low level based on the } \\
\text { subscale factors. }\end{array}$ \\
\hline
\end{tabular}

\section{Research Methods}

This study is a descriptive study. This descriptive study was used to get the reliability and validity value of the inventory build by the Jeffrey Young Scheme Theory. This research consists of 3 phases, which are:

\section{Phase 1: Development of ALI}

The ALI development was based on Jeffrey Young Scheme Theory which is the theory on General Anxiety Disorder. The reference material used was based on articles, journals and books. By referring to these, ALI was built with 21 items and divided into 3 subscales. The items then were given to the professionals for the next phase which is to obtain the reliability value of the inventory.

\section{Phase 2: Content Validity of ALI}

Once the ALI items were developed, the inventory will be distributed to 12 professional panels to revise and assess the inventory on the content accuracy. The professional panels were consisting of two lecturers, one school headmaster, two administrative officers, two counseling teachers, one early education teacher, three occupational therapist and a nurse. The checking will be handled by the professionals in order to obtain the validity value of the inventory. The researchers had prepared a complete copy of the inventory consist of the research introduction and ALI manual, also the appendix to get the professional's opinions and improvement. The evaluations score used is 1 (Totally Disagree) until 10 (Totally Agree).

\section{Phase 3: Reliability Analysis}

In this phase, ALI will be analyzed to get the reliability value. Once the value was obtained, then it will be administered to 45 respondents from age 21 up to 25 years old. The analysis of this study was completed by using the Statistical Package for the Social Sciences (SPSS) in order to obtain the Cronbach Alpha value and assess the level of reliability.

\section{Research Subjects}

The research subjects consist of 12 professional panels that assess the validity value of the inventory and 45 respondents on the age of 21 until 25 years old from different backgrounds. 


\section{Result}

\section{Result Phase 1: Development of ALI}

The development of ALI was handled through literature review based on the past research with appropriate model approach. The ALI was developed based on Young Scheme Theory which is YSQ3 Model Scheme based on mood disturbance and anxiousness.

\section{Result Phase 2: Content Validity Assessment}

Table 4: Comments and Improvement on ALI items

\begin{tabular}{cl}
\hline Professionals & \multicolumn{1}{c}{ Opinions and Improvements } \\
\hline Professional 1 & Change the sentence on the item number 7 in Cognitive subscale \\
Professional 2 & Change the sentence items in the Emotions and Cognitive subscale \\
Professional 3 & Items were suitable \\
Professional 4 & Items were suitable \\
Professional 5 & Items were suitable \\
Professional 6 & Items were suitable \\
Professional 7 & Items were suitable \\
Professional 8 & Items were suitable \\
Professional 9 & Change the sentence in the Emotions Subscale \\
Professional 10 & Items were suitable \\
Professional 11 & The items were suitable with the community backgrounds \\
Professional 12 & Items were suitable
\end{tabular}

Based on the comment and opinions by the professionals, there are items that were suitable and there are also those that were advised to change the items. The researchers referred to the comments given by the professionals to revise the items. Overall, the professionals agreed that the items in ALI is suitable to measure the anxiety level.

Table 5: Validity value on the Total CLI and each subscale

\begin{tabular}{|c|c|c|c|}
\hline Scales/Subscales & $\begin{array}{c}\text { Number of } \\
\text { Items }\end{array}$ & Percentage (\%) & $\begin{array}{c}\text { Professional } \\
\text { Evaluations }\end{array}$ \\
\hline Overall ALI & 21 & $0.617(61.7 \%)$ & Acceptable \\
\hline $\begin{array}{l}\text { Subscale 1: Emotions } \\
\text { (disconnection and denial) }\end{array}$ & 7 & $0.583(58.3 \%)$ & Acceptable \\
\hline $\begin{array}{l}\text { Subscale 2: Behavior } \\
\text { (autonomy impairment and } \\
\text { achievement) }\end{array}$ & 7 & $0.636(63.6 \%)$ & Acceptable \\
\hline $\begin{array}{l}\text { Subscale 3: Cognitive } \\
\text { (vigilance and blocking) }\end{array}$ & 7 & $0.630(63 \%)$ & Acceptable \\
\hline
\end{tabular}

Table 5 shows the ALI content validity value is 0.617 (61.7\%). Every subscale on each of the content validity was $0.583(58.3 \%), 0.636$ (63.6\%), and $0.630(63 \%)$. There are some professional panels mentioned the items were presented in a direct sentence. As for the researchers, the direct sentences is a great feedback because it can make the respondent to understand the items easier and shorter time to answer the inventory. Overall, the ALI validity value was accepted by the panels. 


\section{Result Phase 3: ALI Reliability Analysis}

As for the reliability analysis of ALI, the researchers had used the Statistical Package for Social Sciences (SPSS) version 23. The Cronbach Alpha reliability interpretation assessed on the overall inventory items and also each subscale. Based on Kerlinger (1979), the value of reliability that is more than 0.60 is considered least acceptable. Meanwhile for the Cronbach alpha value between $0.60-0.80$, it is considered moderately acceptable and 0.80 is considered highly acceptable. The Cronbach Alpha value was presented in the Table 6 below.

Table 6: Overall ALI and each subscales reliability value $(n=45)$

\begin{tabular}{|c|c|c|c|}
\hline Scale/Subscale & $\begin{array}{c}\text { Number of } \\
\text { Items }\end{array}$ & Percentage (\%) & Interpretation \\
\hline Overall ALI & 21 & .865 & High \\
\hline $\begin{array}{l}\text { Subscale 1: Emotion } \\
\text { (disconnection and denial) }\end{array}$ & 7 & .710 & Moderately High \\
\hline $\begin{array}{l}\text { Subscale 2: Behavior (autonomy } \\
\text { impairment and achievement) }\end{array}$ & 7 & .578 & Moderate \\
\hline $\begin{array}{l}\text { Subscale 3: Cognitive (vigilance } \\
\text { and blocking) }\end{array}$ & 7 & .766 & Moderately High \\
\hline
\end{tabular}

Overall, the ALI reliability analysis shows a high Cronbach Alpha coefficient with a value of 0.865 . This proves that ALI have a great reliability and can be used by the counsellors. Based on the ALI subscales, the result found that in Subscale 2, behaviors (autonomy impairment or achievement), the reliability value is moderate with 0.578 . Meanwhile for the Subscale 1 , emotion (disconnection and denial) and Subscale, cognitive (vigilance and blocking) have a moderately high value with 0.710 and 0.766 . 
Table 7: Reliability value on each item of ALI

\begin{tabular}{|c|c|c|c|}
\hline Number & Items & Cronbach Alpha & Interpretation \\
\hline 1. & I am useless & .857 & High \\
\hline 2. & I used to have headache & .866 & High \\
\hline 3. & I am hard to make decisions & .866 & High \\
\hline 4. & $\begin{array}{l}\text { I used to feel overwhelm without any } \\
\text { reasons }\end{array}$ & .860 & High \\
\hline 5. & I have trouble with sleeping & .865 & High \\
\hline 6. & I always in a state of stress & .855 & High \\
\hline 7. & $\begin{array}{l}\text { It is hard for me to control my sadness } \\
\text { when I have problems }\end{array}$ & .860 & High \\
\hline 8. & I feel hard to breath & .869 & High \\
\hline 9. & $\begin{array}{l}\text { I always have negative thoughts about } \\
\text { myself }\end{array}$ & .855 & High \\
\hline 10. & $\begin{array}{l}\text { I have lost interest on the things I used } \\
\text { to love }\end{array}$ & .852 & High \\
\hline 11. & I always have muscle cramp problems & .856 & High \\
\hline 12. & I gave up easily & .851 & High \\
\hline 13. & I am humble in the eyes of society & .860 & High \\
\hline 14. & I have digestion problems & .856 & High \\
\hline 15. & $\begin{array}{l}\text { I have a responsibility that is too heavy } \\
\text { to bear }\end{array}$ & .863 & High \\
\hline 16. & I am afraid of things that will happen & .862 & High \\
\hline 17. & $\begin{array}{l}\text { I am nervous when everyone looked at } \\
\text { me }\end{array}$ & .866 & High \\
\hline 18. & I think my future will be dull & .849 & High \\
\hline 19. & I often regret with the decision I made & .849 & High \\
\hline 20. & I tend to avoid meeting crowded people & .859 & High \\
\hline 21. & I hate all of the things & .854 & High \\
\hline
\end{tabular}

Significant level of 0.05

Table 7 shows the reliability analysis on every items of the inventory. The result of the analysis shows the reliability value is above 0.800 and considered as a high value. This analysis is same as mentioned by Kerlinger, as the Cronbach Value that is more than 0.6 gives a great reliability value and acceptable.

\section{Discussion and Suggestion}

This research gives an impact on psychology and counselling in Malaysia. The result of the study shows a high validity and reliability value which proves that it can be use in a counseling session by a counselor. In addition, the development of instrument and research analysis on anxiety level by a counselor is still lacking in Malaysia. Therefore, ALI can be an alternative to the organization that regulates counselors to effectively evaluate the level of anxiety possessed by the clients. Furthermore, although ALI is able to measure and identify the level of anxiety in a person, it is also recommended that further studies to be conducted in order to improve this questionnaire in the future. Therefore, further testing needs to be done to produce a better-quality version of $\mathrm{ALI}$ and can be use includes by various parties directly or indirectly. ALI can also be the basis for a new inventory to measure a person's anxiety level 
especially for those aged 15 years old and above. This is very important because with the availability of $A L I$ inventory, a person who has the symptoms of anxiety can know their level of anxiety whether it is severe or otherwise. Researchers hope that the future studies will not only focus on the theory of General Anxiety Disorder (GAD), but also use the inventory with other related theories. Therefore, since ALI has a high reliability value for counseling practitioners, it is recommended that further studies be conducted by counselors towards the community with unlimited specific groups.

\section{Conclusion}

In a nutshell, this research successfully build the Anxiety Level Inventory based on the Young Scheme Theory (Mood Disorder and Anxiety). Every ALI items that was developed have a high value of validity and reliability. With that, ALI has been successful in measuring the desire aspects by the researchers and can be used by the counselors, teachers and those who applicable on measuring their level of anxiety.

\section{References}

Mohamed, A. M. D., \& Zairazi, R. (2007). Kebimbangan dan kemerosotan prestasi di kalangan atlet lelaki di peringkat universiti. Asian Journal of University Education (AJUE), 3(2), 3756.

Conger, C. D. (1985). THE EFFECTS OF AN ANXIETY REDUCING PROGRAM ON ANXIETY LEVELS OF ELEMENTARY CHILDREN (STRESS, MUSCLE RELAXATION, IMAGERY) (Doctoral dissertation, Kansas State University).

Demir, V., \& Yildirim, B. (2017). Effectiveness of art therapy program on depression anxiety and stress symptom levels of students prepared for university exam. Ege Education Journal, 1(3), 311-344.

Dollard, J., \& Miller, N. E. (1950). Personality and psychotherapy: An analysis in terms of learning, thinking, and culture. New York: McGraw-Hill Book Co.

Freud, S. (1997). Dora: An analysis of a case of hysteria. Simon and Schuster.

Iso-Ahola, S. E., \& Hatfield, B. D. (1986). Psychology of sports: A social psychological approach. William C Brown Pub.

Kelly, G. (1955). Personal construct theory. Theories of Psychopathology and Personality. T. Millon, Editor. Philadelphia: WB.

Kerlinger, F. N. (1979). Foundations of behavioral research. Ed. ke-2. New York: Holt Rinehart \& Winston.

Gould, D., \& Krane, V. (1992). The arousal-athletic performance relationship: Current status and future directions.

Martens, R., Burton, D., Vealey, R. S., Bump, L. A., \& Smith, D. E. (1990). Development and validation of the competitive state anxiety inventory-2. Competitive anxiety in sport, 117-190.

Mokhtarinejad, O., Mirzaian, B., \& Hassanzadeh, R. (2020). Effectiveness of Schema Therapy and Acceptance and Commitment Therapy in Components of Cognitive Emotion Regulation among Patients with Anxiety Disorder. Avicenna Journal of Neuro Psycho Physiology, 7(4), 0-0.

Tarhan, A., Karaman, M. A., \& Nalbant, A. (2020). The effect of counseling on anxiety level from the perspective of ecological systems theory: A quasi-experimental pre-test-posttest control group study. International Journal of Psychology and Educational Studies, $7(3), 58-69$. 